index ecomunicación | no 12(1) 2022 | Páginas 309-333

E-ISSN: 2174-1859 | ISSN: 2444-3239 | Depósito Legal: M-19965-2015

Recibido el 25_05_2021 | Aceptado el 20_10_2021 | Publicado el 15_01_2022

\title{
A REVIEW ON DISCOURSE STUDIES CONCERNING MIGRANTS IN MEDIA PUBLICATIONS FROM BRAZIL AND SOUTH AFRICA: TOWARDS MORE AFRO-LATIN PERSPECTIVES
}

UNA REVISIÓN DE ESTUDIOS DISCURSIVOS SOBRE MIGRANTES EN PUBLICACIONES DE MEDIOS DE BRASIL Y SUDÁFRICA: HACIA PERSPECTIVAS MÁS AFROLATINAS

https://doi.org/10.33732/ixc/12/01Arevie

Gilberto Alves Araújo University of the Witwatersrand \& Universidade Federal do Pará gilbertoa.araujo@yahoo.com.br https://orcid.org/0000-0002-8177-0730

\section{Gizélia Maria da Silva Freitas}

Universidade Federal do Pará gizeliam.freitas@gmail.com https://orcid.org/0000-0003-4685-1188

Wits PMA-Awards (2021) 
Abstract: This paper reviews scientific literature about representation on migrants in Global South media and in other parts of the world, focusing on comparative studies in Brazil and South Africa, and providing suggestions for less Eurocentric perspectives relating to such topic. We resort to a critical review on theoretical references and multiple studies published between the second half of the last century and the beginning of this century. South African comparative research through meta-studies and their quantitative tendency —alongside French Discourse Analysis, Bakhtinian Circle and Greimas' influence in Brazil- indicate how this type of research needs to be expanded in the Global South. This paper recommends the construction of more systematic content-based analyses and the exploration of the different degrees and forms through which balanced or patronizing portrayals on migrants are projected in media. Dislocation from a dominant sociocognitive perspective towards inter-semiotic/sociolinguistic approaches is advisable. This work also suggests that Pan-Africanism, African approaches, and/or Latin-American philosophies should be part of this foundation for migration criticism, especially if these migratory processes are analyzed in media or communication contexts.

Keywords: Media Discourse; Migration; Representation; Latin America; Africa.

Resumen: Este artículo revisa literatura científica sobre la representación de los migrantes en los medios del Sur Global y en otras partes del mundo, centrándose en estudios comparativos en Brasil y Sudáfrica, y brindando sugerencias para perspectivas menos eurocéntricas relativas a dicho tema. Recurrimos a revisión crítica sobre referencias teóricas y múltiples estudios publicados entre la segunda mitad del siglo pasado y principios de este siglo. La investigación comparativa sudafricana a través de meta-estudios y su tendencia cuantitativa -y el análisis del discurso francés, círculo bakhtiniano y la influencia de Greimas en Brasil- indican cómo este tipo de investigación necesita expandirse en el Sur Global. Recomendase la construcción de análisis de contenido más sistemáticos y la exploración de los diferentes grados/formas a través de las cuales se proyectan representaciones equilibradas o condescendientes de migrantes en los medios. Aconsejase la dislocación desde una perspectiva sociocognitiva dominante hacia enfoques inter-semióticos/sociolingüísticos. Sugiérase que el panafricanismo, los enfoques africanos y/o las filosofías latinoamericanas deberían ser parte de esta base de la crítica migratoria, especialmente si estos procesos migratorios se analizan en contextos mediáticos o comunicativos.

Palabras clave: discurso mediático; migración; representación; América Latina; África. 


\section{Introduction}

Our prime goal with this work is to carry out a literature review about research works in media-migration that have been produced on the Global South in the last decades, giving special attention to comparative studies in the Brazilian and South African settings. Thereupon, we expect to provide new suggestions for making discourse studies on this topic advance in the humanities or social sciences, also redirecting the Eurocentric focus of future investigation towards a more inclusive research panorama for the Global South, particularly for Brazil and South Africa. To this end, we resort to the method of critical review on theoretical references, which have been published between mid-20th century and the end of the present decade.

This study also resorts to ResearchGate and Google Scholar as primary search engines. They have been used so we could wade through academic libraries on the specific topics and locations designated for this work. Additionally, the abovementioned timeframe has been established in such a manner because it coincides with the emergence of the first internationally relevant research endeavors on media and migration, not to mention the ascension of the theme since then.

The present paper is extremely important for discourse analysts and other who work within related fields, not only because it reflects on the possibilities of epistemological modes of continual transformation for social sciences and humanities in the Global South, but also because it criticizes some Eurocentric theoretical-methodological markers without abstaining from proposing some (discreet) forms of changing such elements in order to favor rightful appropriation and (re)creation of knowledge by the so-called 'developing' nations. These initial contributions, fruits of a careful analysis of numerous preceding research works, may lead analysts to rethink the ways through which they have conceived this particular theme of migration and media from the Global South. This paper likewise suggests that an advance within the field of discourse studies on media and migratory processes can only be more inclusive and organic if the experiences, philosophies and practices from the Southern region are essential parts of the discussion on human mobility and mass communication. Besides, it suggests that methodological cross-fertilizations centering linguistic and semiotic materiality may be relatively proner to be more consistent, rigorous, significant, dense, reproduceable and adaptable.

In the first segment of this paper, a chronological approach on the scientific literature will be employed. Accordingly, this section is dedicated to an assessment on media-representation and representation-migration literature 
in general and chronologically. In the second segment, our review will work towards a specification of the media-migration as an object of research within the selected countries, Brazil and South Africa. Thus, this section will explore more particular and recent studies about the specific topic in question in the national settings mentioned above. In the third segment, based on the discussions about the analyzed works, we intend to suggest what lines of argumentation, general perspectives, analytical conceptions and methodological approaches could be considered in order to make humanities or social sciences progress in the topic of migrants' representation in the Global South, especially in Brazil and South Africa. At last, we shall summarize our perceptions and findings, also presenting a short version of previous recommendations for future research.

\section{A chronological panorama on media, representation and migration: the state of research on western societies}

Scholar's works regarding discursive representations through media can have part of their origins in the 1950's (Innis, 1951), as well as in the late 1960's or early 1970's, when sociological inquiries started to be made into the press or television, and their process of making and presenting news. Studies such as those by Cirino (1971), Altheide (1974) and Epstein (1973) provide us with extensive accounts about how distorted and biased the news might be, how structural organization of media productions shape news and the projection of facts themselves; or yet, how news media should comply with ethics standards in face of bias, inter alia (Stuart, 1971). Although there seems to be a general intent to develop a sociology of news production and representations in those works, it is not possible to notice a systematic analysis of the media content itself. They indicate a very macrosociological perspective, leaning much more towards a descriptive or prescriptive approach than an explanatory one.

As the abovementioned works suggest, media outlets not only inform about the world, reporting on facts, events and people, but they also construct reality. This means that in the process of production the very organization of media houses, alongside their several structural procedures, shape people's perceptions and social reality, exciting viewers to keep them tuned on each media product, rather than being 'objective' and 'impartial' towards the topics they treat, evidently.

By the late 1970's we can find studies from a microsociological viewpoint, such as those by Tuchman (1978), who employs ethnomethodological techniques. We realize, at this point, how the topic of this literature review has been under the major influence of social sciences paradigms, micro to 
macro-analysis. Instead of considering news as an attempted mimesis of reality, which might be accurate (right) or inaccurate (wrong), at this time and once more scholars used to regard it as a frame that is able to build a social dimension of the world. However, we must point out that even in the early seventies there were works with this microsociological vein (Halloran et al., 1970). Furthermore, works that draw on ideological and discursive aspects of representation in media, even though they were mostly circumscribed within political field, can be found in France, Brazil and South Africa in the sixties and throughout the seventies (Ellul, 1962; Osakabe, 1979; Potter, 1975).

Nevertheless, in that same period, unusual, systematic and contentbased investigations, such as the one by Indra (1979), already emerge. In her work, the North-American scholar deploys a Cultural Studies (CS) framework, although from an anthropological perspective, in order to analyze discourses and media representations on the ethnicities of nationals and immigrants in Canadian newspapers, between 1905 and 1976. She concludes that the Vancouver's press had created several stereotypes about local and foreign social groups. Those stereotypes had been deeply imbricated in value judgements, which offered certain groups more attention and privileged positions to the detriment of others.

Another example of content-based approach, although hybridized with a sociological context study, can be found in the UNESCO publication by Hartmann et al. (1974). Their work points out that the media houses refract and work (under) two types of pressure: one demanding the exclusion of nonwhite immigrants; and another that calls for reduction of discrimination towards those individuals. In addition, the authors indicate that although there are several degrees of ability by the media to shape social attitudes and viceversa, media outlets only exercise an indirect influence on people's perceptions on race and migration. From this study onwards, it seems that culture of mass media and its media-representational dimensions start becoming the center of investigative attention (see Critcher et. al., 1977).

In fact, the transition between the seventies and eighties revealed an unprecedented ascension of CS and its relations with the issue of representation through mass media, as we can see in Fiske \& Hartley (1978) and Hartley (1982). At the same time, several researchers within and outside CS started to deepen their approaches on media and representation also through the lens of (post)structuralism, post-colonialism and critic linguistics, whose origins are closely related to Frankfurt School, particularly to the philosophers Jürgen Habermas and Max Horkheimer (e.g. Fowler et al., 1979). Indeed, continental philosophy, Marxism particularly, started to dominate the perspectives on the 
matter. Despite that, in the last few years there seems to be a growing distance between the abovementioned philosophers and critical theorists working within CDA (Critical Discourse Analysis), for example; as suggested by Haig (2004) and Forchtner (2010). This might have led scholars to develop a new meaning of critique (which tends to deemphasize or disregard injustices by focusing on the 'positive' aspects of power), called 'positive' CDA, relatively farther from Habermas' and Horkheimer's original ideas, or even farther from Marxist perceptions (e.g. O’Regan, 2006; Martin \& Rose, 2003).

Throughout the 1980's, and especially between 1990's and early 2000's, media languages and representational aspects became components of the research objects within the social sciences and humanities, especially in CDA. Publications by discourse analysts Van Dijk (1983a), Kress (1986), Fowler (1991), Fairclough $(1995 ;$ 2000), Wodak (1996a) and Van Leeuwen (Wodak \& van Leeuwen, 1999; Kress \& van Leeuwen, 2001) offer us, from very different viewpoints, a comprehensive panorama of the research on the relations between the abovementioned aspects. Actually, some of them went beyond those elements, in order to explore media representations on minorities and/or migrants (Van Dijk, 1983b, 1987, 1991; Wodak, 1996b; van Leeuwen \& Jaworski, 2003). These studies suggest that migrants or minorities are usually under-represented, portrayed as offenders, threats or undesirables. Additionally, despite variations according to the specific minority/immigrants group, media approaches tend to be unfavorable towards migrants and revolve around migration conflicts. Van Dijk (1983b, 1987, 1991), for example, indicates that the negativity of media discourse, as a cognitive framework, may also lead people to reinforce/develop their negative attitudes or/and to resort to stereotypical cognitions - as it makes way for additional influence on their political views, Wodak (1996b) would add.

Accordingly, the representation of migrants through media, particularly on newspapers articles, has been a relatively common topic of research around the world. In recent years, most researchers seem to employ a discursive approach on media, usually within areas such as linguistics, sociology, geography, anthropology, political science, psychology and media or communication studies. They also appear to focus exclusively on a given nation's newspapers, as a context for analysis, since comparative studies are much more difficult to find. Canada (Yang, 2014; Chan, 2013; Bauder, 2008), United States (Airgood, 2017; Zhu, 2014; Benson, 2013) and western European countries (Bruno, 2016; Maneri, 2012; Liang, 2014) are the most frequent settings for data generation. 
The projects carried out within linguistics generally engage with CDA, SFL and/or Multimodality (van Leeuwen, 2000; Zhu, 2014; Baker 2006; Wodak, 2000). Approaching verbal language, Zhu (2014), for example, indicates a binary nature in the treatment of race and nationality of immigrants in media, their portrayal as illegals, their collectivization, inferiorization and stereotyping. Baker (2006) and Wodak (2000), on their turn, suggest the negative denotations and connotations constructed about immigrants, their media representation as threats and their figurativization through water-based metaphors. At last, Van Leeuwen (2000) points out that visual texts on migrants usually promote dysphemisms, or processes of derogation and denaturalization, reinforcing racism and xenophobia.

Others within Media Studies (MS) prefer to employ mostly a CS approach, with an especial emphasis on semiotics, semiology and multimodality (Liang, 2014). In both areas, or throughout interdisciplinary endeavors between linguistics and communication studies, van Dijk's works and/or his sociocognitive framework are also used as part of methodology (Chan, 2013). Occasionally an integration between sociocognitive and Fairclough's dialectical-relational approach is made, despite the presence of a prominent tendency towards the former, as we can see in Kim (2012) and Yang (2014). Actually, even within other fields, such as psychology and geography, van Dijk's conceptions play a significant role (Bauder, 2008). In these sociognitive studies, frequent findings include the construction and utilization of ingroup self-schemata that derogate or problematize the outgroup in relation to membership criteria, to struggles for recourses, nature of activities, objectives, norms, values, among other elements. In those works, racism and xenophobia emerge as a system of inequality and dominance that is rooted in social cognition; a system that has several forms of depicting migrants/minorities, often entailing topics such as difference or polarization ('us and them'), deviance and threat.

In other instances, triple combination of theoretical-methodological perspectives is possible in CDA. Khosravinik (2009; 2010), for example, outlines a bricolage between van Dijk's sociocognitive, Wodak's discoursehistorical and van Leeuwen's social actors approach. His conclusions, besides confirming results of previous works, reveal that metaphors and macrostructural contexts exercise great influence on the interpretation process of discourses on immigrants. He also argues that all newspapers in his corpora tend to contribute to a similar negative construction of migrants, although they resort to different strategies and several political standpoints.

Extensive interdisciplinary projects have also become more frequent, as we can see in Baker et al. (2008). In these works, the authors combine Wodak's 
discourse-historical approach and Corpus Linguistics (CL) in order to explore discourses concerning refugees, asylum seekers or Islam in the British press. Through discussions that encompass some conceptual dichotomies - such as tabloid-broadsheet, left-right leaning, anti and pro-religious, hard and soft news. The authors demonstrate that Muslims/Arabic migrants are mostly associated to conflict, terror, extremism and religious devotion by the British media. In the corpus they also find 'balanced coverage' or 'good practices', which they refer to in order to recommend media practitioners to positively humanize these migrants, to depict their contributions to British society, and to expand social views on them beyond religion, including art, science, business, education, culture and travel.

Nevertheless, many investigations within cultural anthropology, sociology, political science or communication, for example, rely almost entirely on discursive conceptions therefrom (Maneri, 2012; Lawlor, 2015). Accordingly, others in law studies engage theoretical principles from their own field, in addition to more generalized CDA principles within the media representation and migration subject (Brouwer et al., 2017). Commonly, in the legal field, research projects revolve around the media representation on crime-immigration relations, which many scholars in this area refer to as crimmigration.

Furthermore, we must be aware that CS has still been lending its conceptions to several cross-theoretical perspectives in relation to migration and media representation. Many fields are responsible for this borrowing process, but sociology and communication studies seem to be the most open, as Marco Bruno's (2016) work suggests. By resorting to renown theorists within Communication, Sociology and CS (such as Stuart Hall, David Altheide, Gaye Tuchman and Mauro Wolf), Bruno analyzes the media representation of immigrants in Italy. He concludes that Italian media tend to perceive the nationstate, a territory and an immaterial community, as an unity subject to 'invasion' by foreigners; and immigrants as a permanent threat to security, to western culture and religion(s).

In almost all of the research examples in the previous paragraphs, thematic analysis emphasizing separately race and nationality, sometimes gender (Moore \& Clifford, 2007; Buchanan et al., 2003), are quite present. Buchanan et al. (2003), for example, note that women and children, as asylum seekers and refugees, are rarely depicted in British media, and that young male migrants are largely conceived as a persistent, collectivized or individualized threat. They suggest that by not representing these migrant women and the challenges they face, media outlets occupy that space with images of groups of 
young and 'threating' men, which highlights the meanings of danger, aggression, abuse and corruption attributed to refugees or asylum seekers.

Through most of the abovementioned approachs, we can notice that somehow verbal language and, sporadically, visual features (van Leeuwen, 2000) are considered separately, although in a few cases there are limited attempts to integrate both dimensions (Liang, 2014; Zhu, 2014) with similar results in reference to those we have cited so far.

\section{Media-migration in the Global South: Brazil, South Africa and beyond}

Our incursions into scientific literature suggest that studies generally focus on the Northern regions of the globe, occasionally on North-South or 'centerperiphery' relations, and rarely on South-South or 'Periphery-Periphery' comparisons. Despite that, we could find a few recent comparative studies in Benson (2013), Batziou (2011), Helbling (2014), Chouliaraki et al. (2017), Alves Araújo (2020a), and Airgood (2017), even though they do not approach the Global South or developing countries.

Benson (2013), for example, decides to draw his theoretical-methodological instruments on Pierre Bourdieu and sociology of news production, as well as on the idea of sociocognitive frames to analyze media treatment of immigrants in the United States and France. Disagreeing from Bourdieu, according to whom journalistic practices are weakly institutionalized and highly/internally conventional, Benson argues that USA media is marketoriented and French media is civic-oriented. For him, these and other subframes make both countries' press fairly critical in relation to elites and diverse towards immigrants' voices, whether they include revenue coming from the state or private companies. Besides, he believes a growing affinity between media practitioners' habitus and that assumed by activists in relation to immigrant rights makes the portrayal of immigrants more liberal and favorable towards foreigners.

Also resorting to sociocognitive frames, but farther from sociology of news production, Airgood (2017) confirms that the country of origin and the most common political ideals of the homeland of immigrants can affect these individuals' representation in the media. According to him, in the United Kingdom immigrants in general are more likely to be portrayed in frames of 'politics', 'victims' and 'support'. In the United States media, they tend to be treated through frames such as 'source of conflict', 'threat', and subjects to 'control'. 
Chouliaraki and her colleagues (2017), on their turn, undertake a much more challenging project. They decide to analyze press coverage about immigrants in eight European countries (within a six months period in 2015): Czech Republic, France, Germany, Greece, Hungary, Ireland, Serbia and United Kingdom. Their approach is carried out through what they call a 'systematic content analysis' from a Cultural and Communication Studies perspective (Chouliaraki et al., 2017); although we understand that these two fields alone do not present high potential for this systematicity they refer to, especially in relation to linguistic and/or visual data. In the end, they conclude that: crisis is a macro-frame used in news publication across the continent; media plays a critical role in the evaluation of causes and consequences of this crisis; immigrants are represented often as dangerous/vulnerable; immigrants' individual stories and their cultures are generally omitted, as well as their voices.

In any case, these comparative studies mentioned throughout this subsection only include United States, Canada and European nations. In addition, they are mostly or entirely within sociology, political science, cultural/communication studies, with the exception of Batziou (2011). The Greek scholar applies a multimodal and sociocognitive approach on photographic language of media, in order to correlate Greek and Spanish press, pointing out that newspapers photos frame immigrants as 'others' or outsiders that cannot be incorporated into the host society. Even so, Batziou (2011) tries to encapsulate his methodology within framing theory, while he disregards not only verbal language, but also precious connections between the latter and visual languages.

Helbling (2014) also regulates his comparative study within the cognitive framing theory; and despite paying attention to verbal semiosis, he ends up partially neglecting visual dimension. Based on newspaper data and a comprehensive frame categorization, the author explores framing strategies undertaken by political parties in Austria, France, Germany, Netherlands, United Kingdom and Switzerland between 1999 and 2006. His discussions demonstrate that the framing of immigration depends on several factors, such as the actors' left-right positions and government involvement in the debates, although citizenship models do not emerge as significant elements in the framing process.

If we again turn our attention to the Global South, we will notice how rare comparative investigations of this nature are. Chu (2010) provides us with one of the few studies in this part of the globe. However, his comparisons are made between mainland China and the administrative region of Hong Kong, and not exactly involving two independent states. At last, Chu is another scholar who circumscribes his investigation within cognitive framing theory, 
as we have indicated previously when discussing other comparative works. The Chinese scholar concludes that the responsibility and morality frames, alongside positive evaluation about government, are the most frequently elements employed in Mainland Chinese newspapers, whereas human interest and responsibility frames, together with a neutral tone towards government, are more present in Hong Kong publications.

Accordingly, with regard to Brazilian and South African setting, it is even more uncommon to find comparative researches into representation of migrants through media. In fact, we could not find any involving a comprehensive comparison between both countries, or between one of them and another developing nation, with exception of anthropologist Nyamnjoh's work (2010) and social scientists McDonald's and Jacobs's study (2005). Nonetheless, the former draws conclusions on separate studies regarding Cameroon and South Africa that were already finished and published, that is, he employs a meta-study; therefore, correlations were established year(s) after the basic data generation was concluded. Focusing on nationality-identity and xenophobia, Nyamnjoh (2010) argues that media promote national citizenship and sense of belonging from a large-scale perspective (as if nation-state were the only political unit permitted to provide citizenship in a contemporary world), alongside an assimilationist and territorial standpoint, while neglecting immigrants, refugees or asylum seekers, who often become victims of discrimination and violence.

McDonald and Jacob (2005), on their turn, focus on some Englishspeaking southern African countries only (Zambia, Namibia, Zimbabwe and Botswana) in order to analyze press coverage of xenophobia and several forms of violence against immigrants. The authors indicate that xenophobia is high amongst the Namibians and Zambians, therefore, it is refracted through press publications in that country, which portrays immigrants as criminals or outlaws, often resorting to sensationalism (in case of Namibian newspapers). As for Zimbabwe and Botswana, among many conclusions, the authors suggest that multinational companies operations in both nations, as well as economic-political factors play a part in the reduction of xenophobia, and in keeping the immigration regime relatively less intolerant and unwelcoming.

Despite the valuable findings by these authors, there is a persistent quantitative tendency in their approach. Their discussions revolve almost exclusively around xenophobia and do not extensively approach relations between gender, race and national identity. These scholars also seem to distance themselves from a systematic content analysis on media representa- 
tions, as they resort to dichotomies — such as 'good' and 'bad', 'positive and 'negative', 'pro and anti-immigration' - and to sociology of news production.

In fact, in the South African scenario many works seem to be primarily concentrated within applied social sciences, such as sociology (Danso \& McDonald, 2001; McDonald \& Jacobs, 2005), anthropology (Nyamnjoh, 2010; Coplan, 2009) and law studies (Alfaro-Velcamp \& Shaw, 2016). Most of them confirm media portrayals of immigrant in categories of otherness, illegality, and criminality, as well as people subject to discrimination, prejudice and violence.

Evidently, there are investigations within MS (Kariithi et al., 2017), and occasionally projects within linguistics (Mawadza, 2012) or even crosstheoretical approaches towards statistics-sociology (Smith, 2011). Smith, for example, in an attempt to involve a quantitative analysis in a meta-review approach, decides to analyze several studies about xenophobic events in South Africa in 2008. By resorting to percentages regarding the depth, range and nature (negative versus positive) of press coverage events, Smith (2011) presents interesting numerical evidence and other arguments to convince the reader that the South African print media have been quite xenophobic during this period.

It is interesting to notice that even within South African communication studies there is a quantitative tendency towards CL and sociology, at least in some works (Kariithi et al., 2017). South African linguistics, on its turn, provides us with very specific research objects and deeply multifaceted frameworks. Mawadza (2012), for example, outlines a dense bricolage between dialecticalrelational, sociocognitive and historical-discourse approach, cognitive theory and sociology, involving approximately 575 articles from the SA Media Database. Nonetheless, her topic includes only Zimbabwean immigrants, and her focus is mostly on peculiar concepts from linguistics, such as cognitive metaphor, or from sociology, such as moral panic. In addition, she considers multimodality and emphasizes gender, although she does not seem to discuss specific correlations with national identity and race, or deeper connections between verbal and visual semiosis as she makes general comparisons between these elements.

Among her remarkable findings, we can mention a more balanced/positive/sympathetic media representation of Zimbabwean immigrants in pictures than in verbal language, in which they are often treated as cause of a moral panic. In spite of that, she also confirms previous studies conclusions about these individuals as victims, abusers, criminals or 'strangers'. At last, Mawadza's (2012) multimodal analysis suggests that immigrants' voices are given much more diversity, as images are allegedly considered a 'reflection of reality' itself. 
Through the abovementioned studies, South African scholars do not usually take more than one nation as setting to data generation. However, when they do that, it seems that only English-speaking African countries are taken into account. Except for Mawadza's work (2012), nearly all the other studies lean towards a much more sociological perspective or a quantitative examination. Therefore, a systematic content-based analysis, in conjunction with a more accurate contextual approach, appears to be necessary to make studies advance in the topic of media representation on immigrants, not just in South Africa, but also in Brazil.

In Brazil, researchs on this topic have been carried out mostly within communication studies (Campos, 2015; Dias, 2010; Duarte, 2005; Silva, 2008). Yet, we can find works from linguistics (Dugnani, 2017; Kuwae, 2013; Bueno, 2011), history (Menin, 2016), sociology (Tremacoldi, 2003) and, partially, from an anthropological perspective (Guérios, 2006). These Brazilian projects do not specifically approach African immigrants. Most of them deal with media representation on immigrants, in general, or European, South American, Asian/Arabic ones. Campos (2015), for example, outlines a very broad approach based on CS or post-colonial authors like Stuart Hall and Homi Bhabba, and include Italian, German, Irish, North-American, Asian and African immigrants as subjects. Attempting to understand the meanings or roles attributed to immigrants across 200 news publications between 1808 and 2015, Campos (2015) notices that the Brazilian press assumed mixed positions concerning immigrants. For him, the media representation in these publications range from 'welcoming' assimilation, receptive nationalism, tolerance and hospitality; to racism, xenophobia, hostile or dominant nationalism, as well as incentivization towards a whitening process of the Brazilian population and the making of a new eugeny.

Other Brazilian researchers in communication studies also largely employ CS or post-colonial theory and emphasize verbal language (Dias, 2010; Duarte, 2005), coming to similar conclusions in comparison to Campos (2015), with an exception of Silva (2008), whose work explores media representations on immigrants through personal archives and media photography only. Hence, she tends to put verbal language in the background as she emphasizes the pictures themselves, and occasionally some correlations between both semiosis.

Although Silva (2008) does not consider mass media in her work, resorting to the analysis of personal photos instead, she carries out an interesting study about the media representation of immigrants' gender roles and identities in these images. To this end, she considers in her investigation Ita- 
lian, German and Uruguayan immigrants in Brazil, as well as Brazilian immigrants in Spain, who migrated to their destinations between the beginning of the last century and the first decade of the 21 st century.

Besides indicating that the pictures and several national/regional symbols (depicted in those pictures) are major elements in the process of preserving immigrants' identities in face of an emerging loss, Silva (2008) concludes that women's media representations are tied to subservience, passivity and private life, whereas men are portrayed as agents of authority, activity and public life. Notwithstanding, there are many connotations of freedom and independence that are linked to women's media representations as leaders in a household or in the immigration process itself, especially in the beginning of this century.

Despite a wide panorama offered by the majority, some media scholars in Brazil engage a very definite category of immigrant, such as Dias (2010), who investigates radio representations on identity of Bolivians living in São Paulo city. He suggests that, differently from conventional mass media, Bolivian radio stations and their programs act as organic representatives of these immigrants' voices, joining their struggles, and maintaining in them a sense of authentic or preserved national identity. Nearly all the other studies in Brazil also deal with issues of national identity or race, and occasionally gender.

In Brazilian linguistics, researches on this matter does not generally involve CDA, as some may assume. Perhaps the large influence of French Discourse Analysis and the Bakhtinian Circle could have played a role in the country's investigation dynamics (for other topics with the same theory see also Alves Araújo, 2018; 2019; 2020b). In fact, this national linguistics offers a prominent theoretical diversity. On the one hand, we have researchers who build a framework mostly based on Mikhail Bakthin's dialogism (Dugnani, 2017). On the other hand, there are scholars who draw perspectives from the semiotics of Algirdas Greimas (Bueno, 2011).

However, CDA is still present in the Brazilian setting, as we can observe in Kuwae's study (2013). She combines the theory of social actors, by van Leeuwen, some categories of dialectical-relational approach, by Fairclough, and other concepts by Cultural theorist Edward Thompson. The Brazilian researcher analyzes a variety of public documents and media publications in order to discuss representations on Japanese immigrants in the first half of the 20th century, with special attention to the period of the Second Great War. National identity and race are the two key aspects explored in her work, and, once more, the emphasis is on verbal language. Through her analysis, she realizes that the construction of Japanese immigrants' identi- 
ties across Brazilian media was polemic, and that these subjects faced racism and several forms of prejudice, which produced different effects in their social, economic and cultural life.

In the abovementioned fields and other areas, such as sociology, history and anthropology, a discursive approach seems to be quite central. In this sense, race and national identity emerge as the most relevant aspects for analysis and discussion. Gender, therefore, does not appear to be so important in Brazilian researches regarding media representation on immigrants.

\section{Preliminary results and recommendations}

In view of the previous sections, we recommend that future research projects should analyze and understand not only the negative aspects of immigrants' media representation, but likewise the several degrees and ways through which more balanced, humane or favorable portrayals are constructed -if we can, in fact, find them. Concomitantly, these investigative endeavors should also emphasize an analysis of those depictions that seem humanitarian but are deeply enrooted in patronizing and paternalist views of the world. We decide to include these extra perspectives because, among many reasons, there seems to already exist a considerable body of literature that primarily discusses the 'negative' aspects of media depiction on immigrants. Therefore, researchers should feel responsible for extending this approach in order to propose a more comprehensive project.

Additionally, it should be future projects' major goal to better understand this topic in the context of developing countries or the Global South, making progress in comparative studies that carefully consider this part of the planet instead of repeating so many works that approach 'developed', 'first world' or 'elite' nations, such as Canada, USA and those in western Europe.

In other words, moving away from the North American-Eurocentric viewpoints assumed within this topic will also allow scholars to explore the relations between colonized countries and their immigrants, such as in the case of Brazil and South Africa. On one side, there is Brazil with its history of accepting white immigrants in an attempt to whiten the population. On the other side, we have South Africa with its history entailing very racialized lines to divide groups' positionings in social organization and political spectrum/debates. Besides that, future comparative studies should present us with an opportunity to more properly discuss the reality of historically oppressed regions who might also became, in the process of their "emancipation" through neoliberal capitalism and intellectual American-Eurocentrism, oppressors towards foreigners, especially if these come from poor countries, if they are female, genderqueer and/or black. 
More than a prospection into nationality and political-economic/sociocultural relations between immigrant's original countries and their destination states, comparative research projects should be about the construction and perception of gender and racial-ethnic identities in media, as well as the connections that bring the three together (nationality, gender and race). In this sense, in order to carry out an investigation with such a nature, scholars should pay particular attention not just to verbal language data, but likewise to the visual information, attempting to maintain a proportional and correlational analysis of the two.

Furthermore, instead of beginning the study from the representations themselves in media, often disregarding the process of insertion of immigrants in media publications, future comparative projects should also resort to the sociology of media production as both reference to theoretical discussions and part of the analytical process itself. Therefore, researchers will be able to better understand how, to what extent, and for what possible reasons immigrants become part of the news media, something that most scholars do not seem to methodically do, as shown in this brief literature review. At the same time, although sociology of news is brought in, it is necessary to undertake this type of approach without decharacterizing its systematic and content-based nature, trying to keep, as accurate and clear as possible, its theoretical-methodological conceptions, instruments and procedures.

Once more, we reiterate that the theories and methods connected to future comparative research should be able to redirect the investigation from a dominant sociocognitive perspective towards a more inter-communicative/inter-semiotic and sociolinguistic approach, in which the processing of discursive meanings is not restricted to their presentation or reception, but cautiously includes aspects of media production/circulation.

\section{Additional discussion and conclusions}

In regard to theoretical-methodological innovation, we anticipate that it is also necessary a clearer articulation between communication or MS, CS, CDA, and $\mathrm{CL}$ around the conceptions of race, gender and nationality. Among the suggestions we make in this work, there is a theoretical rearrangement with respect to the operation of these conceptions, and other notions or procedures derived from any column of that quartet; a bricolage, many would say.

Furthermore, we need to recognize that conceptual unities such as gender, race and nationality are sporadically and/or separately mobilized through the research works we have mentioned so far. This seems to occur in such a way that we can comprehend very little (if at all) about how those three categories are built correlatively and projected through media; how 
they interact and, above all, how they circulate throughout the discourse of different subjects and social institutions in the Global South.

Notwithstanding an apparent methodological advance, the integration between CDA and CL appears to be quite recurrent in research works. However, we might not be able to say the same about the relations between CDA, CS and some categories of MS; probably because many investigative enterprises make these connections implicit, and/or naturalized in view of the historical proximity concerning some of these theoretical perspectives. Hence, when we associate the four theoretical fields (MS, CDA, CL and CS), we also increase the possibilities for innovation around those conceptual unities we mentioned.

In fact, CS, MS and CDA share multiple similarities in respect to the definition of many terms, what not only reveals their historical contiguity, but also facilitates a more consistent articulation between them. In spite of that, it is necessary to admit that CS and MS become less able to employ a deeper analysis on the complexity of institutional and other power structures in order to acknowledge prospects of social change and to integrate theoretical applications with communities/networks of concrete individuals (Bennett, 1998).

Under those circumstances, CDA (based on Systemic-Functional Linguistics [SFL] or associated to $\mathrm{CL}$ ) emerges as a theory offering more potential for a systematic or repeatable comprehension into the linguistic and visual dimension. This approach seems to offer the most adequate tools, especially if the goal is to recognize and explain modifications in identity performativity and its media representations. In methodological terms, we can obtain a more precise and close identification of the evidence upon which to base data analysis; not to mention that we minimize the issues of the analyst's unfair bias or noxious tendencies of background; as suggested by Grossberg et al. (1992) and Steedman (1992).

On the other hand, by posing culture and media as central, CS and MS can also support a proper emphasis on characteristics and performances of the subjects and media organizations, taking as reference the sense of community/collectivity and the discursive practices themselves; as implied by Grossberg $(1997,1998)$. Thus, researchers can keep the objects of analysis in a fruitful perspective, illustrating more comprehensively the construction of meanings in society and the meaning-making processes or practices through media (Lewis, 2002), since communication or semiosis, and culture are essential for both approaches.

In addition, like CDA (in association with SFL and CL), CS and MS might be quite deconstructive theories, offering a sound critique, not only about the Western aesthetics and construction of social reality in 'artifacts', 
but also on power relations in diverse settings. If the first field tends to focus on discourse and linguistic (visual/verbal) data analysis, the other two always remind us of contextualization, and any component of the triad can be site for criticism and action.

Nonetheless, a significant number of other problems still emerge from those relations and mutual support between the three perspectives. The most frequently suggested (see Baker, 2006; Grundmann \& Krishnamurthy, 2010) are the inability to handle large data; persistent unfair or unprincipled bias by the analysts; low potential for demonstrating patterns, among other issues. At this point CL and SFL are brought to the analysis work in order to minimize those problems. Therefore, by dealing with a quantitative basis, CL is able to approach extensive data group, as it protects the linguistic production against superficial or over-interpretation, or yet the "pick and choose" perspective, which seems quite common in discourse studies. Furthermore, CL enables us to identify lexical-grammatical patterns drawn from SFL, as well as patterns of repetition or intensity, not to mention the potential for reducing the researcher's unjustified bias, as we mentioned before.

The use of this quadripartite theoretical system does not seem to be very common when it comes to immigration settings in the Global South, especially when dealing with concepts like gender, race and nationality. There are several studies that involve the connections between language and race (Orelus, 2017), language and gender (Sunderland, 2004) and language and national identity (Mateos, 2014). Others approach similar matters from CDA and CS perspective (Carpentier \& Spinoy, 2008), or CDA and CL point of view (Baker, 2006). However, we have not found a comparative study that openly integrates the four of those perspectives as it tries to make connections between race/gender and nationality in the context of binational media in the Global South, or in Brazil-South Africa context for example. Therefore, we are inclined to recognize that an investigation proposal from this perspective would be promising and quite original, as we have been arguing so far.

At last, since a significant number of the works that approach media representation on immigrants nowadays can be related to CDA, we suggest that CDA's reference for critique should be reviewed, that is, its foundations should be clearer or better defined. Therefore, researchers must establish elements that are not openly laid out in CDA, namely the validation and grounding of critical standards, which the analyst can depend on. We suggest so because it seems to us that, generally, in CDA works critique is not justified or reliable (Forchtner, 2010) as reference to the act of (self-)reflection itself, whether towards theory or practice, or both. 
If we can delineate this referential critique, researchers might be able to consider how to answer questions related to the reasons why they decided to challenge and fight prejudice, discrimination, racism, gender inequalities and other forms of symbolic and concrete violence against immigrants in the Global South. Once researchers have 'uncovered' the many factors and processes regarding these types of violence, they need to contrast those realities and practices with defined principles and references of democracy, freedom, fairness and equality. Thus, they might resort to a reference for critique that comes Pan-Africanism and African Womanism, as well as Latin American philosophy (see Hudson-Weems, 1993; Kerenga, 1998; Boff, 1981; Hierro, [1985] 1990; Mills, 2003).

If researchers that deal with media-migration wish to carry out their work as a socially responsible, committed and transformative teleology (McKenna, 2004), as critical humanities and social sciences should do, they have to make clearer their foundations for critical standards and praxis. Otherwise, they will be always dealing with rightful criticism of those who accuse discourse theorists as improperly biased, and CDA, for example, as an unprincipled theory (see Widdowson, 1998; Stubbs, 1997).

\section{Bibliographic references}

AIRGOOD, B. (2017). Immigrant representation: a content analysis of media narratives of immigrants in U.K. and U.S. publications (Master's dissertation). Michigan State University, East Lansing.

\section{doi.org/doi:10.25335/M5GK3D}

AlFARO-VELCAMP, T. \& SHAW, M. (2016). Please GO HOME and BUILD Africa: criminalizing immigrants in South Africa. Journal of Southern African Studies, 42(5), 983-998.

\section{doi.org/10.1080/03057070.2016.1211805}

ALTHEIDE, D.L. (1974). Creating reality: how TV news distorts reality. Beverly Hills: Sage.

AlVES ARAÚJO, G. (2018). O Tocantins e seu ensino de inglês na proposta curricular para o ensino médio: entre expectativas e silenciamento. Revista Leia Escola, 18(3), 145-163. dx.doi.org/10.35572/rle.v18i3.1175

ALVES ARAÚJO, G. (2019). Discurso docente sobre a língua inglesa: concepções de ensino-aprendizagem, docência e linguagem. Cadernos de Linguagem e Sociedade, 20(2), 226-253. doi.org/10.26512/les.v20i2.25374

Alves ARAÚJO, G. (2020a). Black migrants in Brazilian and South African tabloids: representations on the Global South. Journal of Global Diaspora and Media, 1(1), 35-53. doi.org/10.1386/gdm_00003_1 
AlVes ARAÚJo, G. (2020b). Teachers' discourse on English language teaching: faces of resistance and neo-colonialism. International Journal of Critical Diversity Studies, 2(1), 71-91. doi.org/10.13169/intecritdivestud.2.1.0071

BAKER, P. et al. (2008). A useful methodological synergy? Combining critical discourse analysis and corpus linguistics to examine discourses of refugees and asylum seekers in the UK press. Discourse and Society, 19(3), 273-306. doi.org/10.1177/0957926508088962

BAKER, P. (2006). Using Corpora in Discourse Analysis. London: Continuum. doi.org/10.1093/applin/amm006

BATZIOU, A. (2011). Framing 'otherness' in press photographs: The case of immigrants in Greece and Spain. Journal of Media Practice, 12(1), 41-60. doi.org/10.1386/jmpr.12.1.41_1

BAUDER, H. (2008). Dialectics of humanitarian immigration and national identity in Canadian public discourse. Psychosocial Dimensions of the Refugee Experience, 25(1), 84-93.

\section{doi.org/10.25071/1920-7336.21401}

BENNETT, T. (1998). Culture: A reformer's science. St. Leonards: Allen and Unwin.

BENSON, R. (2013). Shaping immigration news: a French-American comparison. New York: Cambridge University Press.

BofF, L. (1981). O caminhar da igreja com os oprimidos: Do vale das lágrimas à terra prometida. Rio de Janeiro: Codecri

BROUWER, J. et al. (2017). Framing migration and the process of crimmigration: a systematic analysis of the media representation of unauthorized immigrants in the Netherlands. European Journal of Criminology, 14(1), 100-119. doi.org/10.1177/1477370816640136

BRUNO, M. (2016). Media representations of immigrants in Italy: framing real and symbolic borders. Revista Interdisciplinar da Mobilidade Humana, 46(1), 45-58. doi.org/10.1590/1980-85852503880004604

BUCHANAN, S. et al. (2003). What's the story? Results from research into media coverage of refugees and asylum seekers in the UK. London: Article 19.

BuEno, A.M. (2011). Representações discursivas do imigrante no Brasil a partir de 1945 (Doctoral thesis). USP, São Paulo. doi.org/10.11606/T.8.2011.tde-17042012-145810

CAMPOS, G.B. de (2015). Dois séculos de imigração no Brasil: a construção da imagem e papel social dos estrangeiros pela imprensa entre 1808 e 2015 (Doctoral thesis). Universidade Federal do Rio de Janeiro, Rio de Janeiro.

CARPENTIER, N. \& SPINOY, E. (2008). Discourse theory and cultural analysis: media, arts and literature. New York: Hampton Press. 
CHAN, W. (2013). News media representations of immigrants in the Canadian criminal justice system. Recuperado de https://tinyurl.com/2p8ry39f

ChOUliaraKi, L. et al. (2017). The European "migration crisis" and the media: A cross-European press content analysis. London: The London School of Economics and Political Science.

CHU, K. (2010). Framing Chinese migrant workers: Aa comparison of media coverage in Mainland China and Hong Kong (Master's dissertation). Iowa State University, Ames.

CiRINO, R. (1971). Don't blame the people. New York: Random House and Vintage Books.

COPLAN, D.B. (2009). Innocent violence: social exclusion, identity, and the press in an African democracy. Identities: Global Studies in Culture and Power, 16(3), 367-389. doi.org/10.1080/10702890902861420

CRITCHER, C. et al. (1977). Race in the provincial press: A case study of five West Midlands papers. In UNESCO, Ethnicity in the media (pp. 25-192). Paris: Unesco.

DANSO, R. \& MCDONALD, D.A. (2001). Writing xenophobia: immigration and the print media in Post-Apartheid South Africa. Africa Today, 48(3), 115137. doi.org/10.1353/at.2001.0050

DiAS, D.B. (2010). Mídia, imigração e identidade(s): as rádios bolivianas de São Paulo (Master's dissertation). PUC-Brasília, Brasília.

DUARTE, P. R. (2005). A diáspora uruguaia nas interações comunicacionais e midiáticas dos imigrantes no sul do Brasil (Doctoral thesis). Universidade do Vale do Rio dos Sinos, São Leopoldo.

DuGNANI, B.L.F. (2017). Imagens discursivas de imigrantes e suas implicações no discurso de receptividade do brasileiro na imprensa nacional: uma perspectiva dialógica (Doctoral thesis). PUC-São Paulo, São Paulo.

Ellul, J. (1962). Propagandes. Paris: Armand Colin.

EPSTEIN, E.J. (1973). News from nowhere. New York: Random House and Vintage Books.

FAIRCLOUGH, N. (2000). Critical analysis of media discourse. In: MARRIS, P. \& Thornham, S. (eds.). Media studies (pp. 308-325). New York: New York University Press.

FAIRCLOUGH, N. (1995). Media Discourse. London: Edward Arnold.

FISKE, J. \& Hartley, J. (1978). Reading television. London: Methuen.

FoRCHTNER, B. (2010). Jürgen Habermas' language-philosophy and the critical study of language. Critical Approaches to Discourse Analysis across Disciplines, 4(1), pp. 18-37.

FowLER, R. et al. (1979). Language and Social Control. London: Routledge. 
FOWLER, R. (1991). Language in the news: discourse and ideology in the press. London: Routledge.

GrossBERG, L. et al. (eds.) (1992). Cultural Studies. New York: Routledge.

GROSSBERG, L. (1997). Bringing it all back home: essays on Cultural Studies. Durham: Duke University Press.

GrossBerg, L. (1998). The Cultural Studies' Crossroads Blues. European Cultural Studies, 1(1), 65-82. doi.org/10.1177/136754949800100105

GRUNDMANN, R. \& KRISHNAMURTHY, R. (2010). The discourse of climate change: a corpus-based approach. Critical Approaches to Discourse Analysis Across Disciplines, 4(2), 125-146.

GUÉRIOS, P.R. (2006). Memória, identidade e religião entre imigrantes rutenos e seus descendentes no Paraná (Doctoral thesis). UFRJ, Rio de Janeiro.

HAIG, E. (2004). Some observations on the critique of Critical Discourse Analysis. Studies in Language and Culture, 25(2), 129-150.

HALlORAN, J.D. et al. (1970). Demonstrations and communication: a case study. London: Penguin Books.

HARTLEY, J. (1982). Understanding news. London: Methuen.

HARTMANN, P. et al. (1974). Race as news: a study of the handling of race in the British national press from 1963 to 1970. Recuperado de https: //tinyurl.com/yc2tjuvz

HELBLING, M. (2014). Framing immigration in Western Europe. Journal of Ethnic and Migration Studies, 40(1), 21-41. doi.org/10.1080/1369183X.2013.830888

HIERRO, G. ([1985] 1990). Ética y Feminismo. Mexico City: UNAM Press.

HUdSON-WEEMS, C. (1993). Africana Womanism: Reclaiming Ourselves. New York: Bedford.

INDRA, D.M. (1979). Ethnicity, social stratification and opinion formation: an analysis of ethnic portrayal in the Vancouver Press, 1905-1976 (Doctoral thesis). Simon Fraser University, Burnaby.

InNIS, H.A. (1951). The bias of communication. Toronto: University of Toronto Press.

KARIITHI, N. et al. (2017). Media portrayal of immigration in the South African media, 2011-2015. The Scalabrini Institute for Human Mobility in AfricaSIHMA, working paper, June, pp. 1-32.

Kerenga, M. (1998). Kwanzaa: A Celebration of Family, Community and Culture. Los Angeles: U.S.P.

KHOSRAVINIK, M. (2009). The representation of refugees, asylum seekers and immigrants in British newspapers during the Balkan conflict (1999) and the British general election (2005). Discourse and Society, 20(4), 477-498. doi.org/10.1177/0957926509104024 
KHOSRAVINIK, M. (2010). The representation of refugees, asylum seekers and immigrants in British newspapers. Journal of Language and Politics, 9(1), 1-28. doi.org/10.1075/jlp.9.1.01kho

KIM, S. (2012). Racism in the global era: analysis of Korean media discourse around migrants, 1990-2009. Discourse and Society, 23(6), 657-678. doi.org/10.1177/0957926512455381

KRESS, G. \& VAN LEEUWEN, T. (2001). Multimodal discourse: the modes and media of contemporary communication. London: Arnold.

KRESS, G. (1986). Language in the media: the construction of the domains of public and private. Media, Culture and Society, 8(1), 395-419. doi.org/10.1177/0163443786008004003

KuWAE, L.H.Y. (2013). Cem anos de imigração japonesa: a construção midiática da identidade do imigrante japonês (Doctoral thesis). UnB, Brasília.

LAWLOR, A. (2015). Local and national accounts of immigration framing in a cross-national perspective. Journal of Ethnic and Migration Studies, 41(6), 918-941. doi.org/10.1080/1369183X.2014.1001625

LEWIS, J. (2002). Cultural studies: the basic. New York: SAGE-USA.

LIANG, X. (2014). Media representation of nationalism and immigration: a case study of Jamie's Great Britain (Master's dissertation). London School of Economics, London.

MANERI, M. (2012). L'immigrazione nei media: la traduzione di pratiche di controlo nel linguaggio in cui viviamo. Revista della Societá Italiana di Antropologia Culturale, 1(1), 24-37.

doi.org/10.7340/anuac2239-625X-8

MARTIN, J.R. \& Rose, D. (2003). Working with discourse: meaning beyond the clause. London: Continuum.

MATEOS, P. (2014). Names, ethnicity and populations: tracing identity in space. Berlin: Springer.

MAWADZA, A.M. (2012). The Zimbabwean threat: media representations of immigrants in the South African media (Doctoral thesis). University of the Western Cape, Cape Town.

MCDONALD, D.A. \& JACOBS, S. (2005). (Re)writing xenophobia: understanding press coverage of cross-border migration in Southern Africa. Journal of Contemporary African Studies, 23(3), 295-325. doi.org/10.1080/02589000500274050

MCKennA, B. (2004). Critical discourse studies: Where to from here? Critical Discourse Studies, 1(1), 9-39.

doi.org/10.1080/17405900410001674498 
MENIN, A.F. (2016). Entre 'velhos' e novos imigrantes: memórias e representações em Caxias do Sul no tempo presente (2005 - 2016) (Master's dissertation). UESC, Florianópolis.

Mills, C.W. (2003). From Class to Race: Essays in White Marxism and Black Radicalism. Lanham: Rowman and Littlefield.

Moore, K. \& Clifford, S. (2007). The gendered use of the media by asylum seekers in Britain. Gender and Development, 15(3), 451-466. dx.doi.org/10.1080/13552070701630616

NYAMNJOH, F.B. (2010). Racism, ethnicity and the media in Africa: reflections inspired by studies of xenophobia in Cameroon and South Africa. Africa Spectrum, 45(1), 57-93. doi.org/10.1177/000203971004500103

O'REGAN, J.P. (2006). The text as a critical object: on theorising exegetic procedure in classroom-based Critical Discourse Analysis (Doctoral Thesis). University of London, London.

\section{doi.org/10.1080/17405900600908111}

ORELUS, P.W. (2017). Language, race, and power in schools: a Critical Discourse Analysis. London: Routledge.

OSAKABE, H. (1979). Argumento e discurso político. São Paulo: Kairós.

POTTER, E. (1975). The press as opposition: the political role of South African newspapers. London: Chatto and Windus.

SILVA, D.T. da (2008). Fotografias que revelam imagens da imigração: pertencimento e gênero como faces identitárias (Doctoral thesis). Universidade do Vale do Rio dos Sinos, São Leopoldo.

SMITH, M.J. (2011). Violence, xenophobia and the media: a review of the South African media's coverage of xenophobia and the xenophobic violence prior to and including the events of 2008. Politikon, 38(1), 111-129.

\section{doi.org/10.1080/02589346.2011.548673}

STEEDMAN, C. (1992). Culture, Cultural Studies and the historians. In: GrossberG, L. et. al. (eds.). Cultural Studies (pp. 613-621). New York: Routledge.

STUART, K.W. (1977). The newspaperman's guide to the law. 2 ed. Durban: Butterworth.

STUBBS, M. (1997). Whorf's children: critical comments on Critical Discourse Analysis (CDA). In A. RYAN \& A. WRAY (eds.). Evolving models of language (pp. 100-116). Clevedon: British Association for Applied Linguistics.

Sunderland, J. (2004). Gendered discourses. London: Palgrave and Macmillan. TREMACOLDI, P.R. (2003). Mídia e imigrantes latino-americanos nos Estados Unidos: uma relação de forças (Master's dissertation). Unicamp, Campinas. Tuchman, G. (1978). Making news. New York: Free Press. 
VAN DIJK, T.A. (1983a). Discourse analysis: its development and application to the structure of news. Journal of Communication, 33(1), 20-43. doi.org/10.1111/j.1460-2466.1983.tb02386.x

VAN DIJK, T.A. (1983b). Minderheden in the media. Amsterdam: Socialistische Uitgeverij Amsterdam.

VAN DIJK, T.A. (1987). Mediating racism: the role of the media in the reproduction of racism. In: WODAK, R. (ed.). Language, power and ideology (pp. 199-226). Amsterdam: Benjamins.

VAN DIJK, T.A. (1991). Racism and the press. London: Routledge.

VAN LEEUWEN, T. \& JAWORSKI, A. (2003). The discourses of war photography: photojournalistic representations of the Palestinian-Israeli war. Journal of Language and Politics, 1(2), 255-275. doi.org/10.1075/jlp.1.2.06lee

VAN LEEUWEN, T. (2000) Visual racism. In: REISIGL, R. \& WODAK, R. (eds.). The semiotics of racism: approaches in critical discourse analysis (pp. 363391). Vienna: Passagen Verlag.

WIDDOWSON, H.G. (1998). The theory and practice of critical discourse analysis. Applied Linguistics, 19(1), 136-151.

doi.org/10.1093/applin/19.1.136

WODAK, R. (1996a). The genesis of racist discourse in Austria since 1989. In: CALDAS-COULTHARD, C.R. \& COUlTHARD, M. (eds.). Texts and practices: readings in critical discourse analysis (pp. 107-128). London: Routledge.

WODAK, R. (1996b). Others in discourse - Racism and antisemitism in present day Austria. Research on Democracy and Society, 3(1), 275-296.

WODAK, R. \& VAN LEEUWEN, T. (1999). Legitimizing immigration control: a discourse-historical analysis. Discourse Studies, 1(1), 83-119. doi.org/10.1177/1461445699001001005

WODAK, R. (2000). We demand that foreigners adapt to our life-style: political discourse on immigration laws in Austria and the United Kingdom. In: WODAK, R. et al. (ed.). Combating Racial Discrimination (pp. 217237). Oxford: Berg.

YANG, J. (2014). Representations of immigrant students in Canadian print news media: a Critical Discourse Analysis. Critical Intersections in Education, 2(1), 27-43.

ZHU, Z. (2014). Making the 'invisible' a 'visible problem' - The representation of Chinese illegal immigrants in U.S. newspapers". Journal of Chinese Overseas, 10(1), 61-90. 